\title{
Purifying Sufism: Observations on the Marginalization and Exclusion of Undesirable and Rejected Elements in the Earlier Middle Period (late fourth/tenth to mid-seventh/thirteenth centuries)*
}

\author{
Purificando el sufismo: observaciones sobre la marginación \\ y exclusión de elementos indeseables y rechazados \\ en el Período medio temprano \\ (finales s. IV/X-mediados s. VII/XIII)
}

Daphna Ephrat

Open University, Israel

This article offers observations on the process of differentiation and purification within premodern Sufism during a seminal period in the institutionalization of the Sufi taríqa as a Path to God and as a community of followers. Drawing on manuals and narratives by prominent articulators and representatives of the emerging mainstream Sufi tradition, the article highlights the discursive and actual mechanisms they employed to delineate the borderlines of affiliation with the communities of the genuine Sufis, disentangle the solid-core from lay affiliates, and exclude undesirable elements wrongly associated with Sufism. The construction of higher barriers between mainstream Sufism and its margins is closely tied to the spread of popular forms of Sufism and a new kind of antinomianism that gained popularity in the public sphere, beginning in the late sixth/twelfth century. The final part of the article considers the involvement of the political rulers of the time in the inner dynamics
Este artículo ofrece una serie de observaciones sobre el proceso de diferenciación y purificación dentro del sufismo pre-moderno durante un periodo crucial para la institucionalización de las tarīqa-s sufíes como una Vía hacia Dios y como una comunidad de seguidores. Basándose en manuales y en narraciones de autores prominentes y representantes de la tradición sufí mainstream emergente, este artículo pone de relieve los mecanismos discursivos que emplearon para marcar los bordes de la afiliación con comunidades de sufíes genuinos, separar el núcleo central de los afiliados externos, y excluir a los elementos indeseables erróneamente asociados con el sufismo. La construcción de fronteras entre el sufismo mainstream y sus márgenes está estrechamente vinculada a la difusión de formas populares de sufismo y un nuevo tipo de antinomianismo que ganó popularidad en la esfera pública, comenzando en el siglo VI/XII. En la parte final del artículo se analiza la inter-

* I wish to acknowledge the generous support of The Israel Science Foundation (ISF) grant no. 46/11, for research on "In the footsteps of the Prophet: spiritual leadership in a medieval Islamic setting." 
of Sufism. My main conclusion is that by patronizing mainstream Sufis and supporting arbiters of true religion in the public sphere, the ruling elite of military lords in the Arab Near East played a significant role in marginalizing the undesirable and rejected elements and in strengthening the mainstream Sunni camp against its rivals.

Key words: Sufism; Pseudo-Sufis; Lay affiliates; Antinomians; Spiritual authority; Ruling authorities; The Syrian urban scene; Late fourth/tenth to mid-seventh/thirteenth centuries. vención de los gobernantes políticos de la época en las dinámicas internas del sufismo. La principal conclusión es que mediante el patronazgo de los sufíes mainstream y apoyando a quienes actuaban como árbitros de la verdadera religión, la élite gobernante de los señores militares en el Oriente Próximo árabe desempeñó un papel significativo en la marginación de los elementos indeseables y rechazados y en el fortalecimiento del sufismo mainstream contra sus rivales.

Palabras clave: Sufismo; pseudo-sufíes; afiliados; antinomianismo; autoridad espiritual; autoridades gobernantes; el escenario urbano sirio; finales s. IV/X-mediados s. VII/XIII.

\section{Introduction}

Scholarly literature has displayed at length the harsh condemnation of certain beliefs and practices ascribed to Sufis, or even opposition to the whole of Sufism, in proto-Sunni circles that began very early and intensified in medieval Islam with the writings of renowned Hanbalis such as Ibn al-Jawzī (d. 597/1200) and Ibn Taymiyya (d. 728/1328). In this article, I propose to shift the focus of inquiry from outside critics to the discursive and actual efforts made by Sufi shaykhs to cleanse their tradition and communities of suspect and rejected groups. My overall observation is that during the late fourth/tenth to midseventh/thirteenth centuries (referred to by Marshall Hodgson as the earlier middle period), ${ }^{1}$ the old dissensions between legalists and Sufis, the fuqah $\bar{a}$ ' and fuqara $\bar{a}$, gave way to a rigorous process of differentiation and purification within Sufism itself. ${ }^{2}$ A mainstream Sufi tradition,

1 The term Islamic middle periods is tied to the peculiarities of Islamic history in general and Sufism in particular: Hodgson, The Venture of Islam: Conscience and History in a World Civilization, especially, pp. 3-11.

2 Some aspects of this process are considered in recent scholarship that focuses attention on the institutionalization of Sufism and the formation of Sufi communities in late Abbasid Baghdad. This includes Frenkel, "Mutasawwifa versus Fuqara': Notes Concerning Sufi Discourse in Mamluk Syria," pp. 291-307; Ohlander, Sufism in an Age of Transition: 'Umar al-Suhrawardī and the Rise of the Islamic Mystical Brotherhoods, especially, chaps. 3 and 4; Salamah-Qudsi, "The Idea of Tashabbuh in Sufi Communities and Literature of the Late $6^{\text {th }} / 12^{\text {th }}$ and Early $7^{\text {th }} / 13^{\text {th }}$ Century in Baghdad". 
which was first formulated in the teachings of a number of late fourth/tenth-century Sufi religious scholars, became a legitimate version of the prophetic sunna and integrated itself into mainstream Sunnism and the scholarly world of the established legal schools. ${ }^{3}$ Articulators and prominent representatives of the tradition that reconciled between Sufism and the law-most famously Abū l-Qāsim alQushayrī (d. 465/1072) and Abū Ḥāmid al-Ghazālī (d. 505/1111) -defined the essential concepts and practices to which those who considered themselves Sufis should adhere and undertake to disseminate. A social category of "true" Sufis was emerging. They set themselves apart from whom they identified as "pseudo-Sufis" (mutașawwifa) and frivolous "imitators" (mutashabbihūn), and worked on ways to bring the Sufi tradition and community under some form of control. Higher barriers between true Sufism and its margins were constructed towards the end of the earlier middle period, in the face of the spread of popular forms of Sufism and a new kind of antinomianism that gained popularity in the public sphere. ${ }^{4}$

How the formulators and masters of the tradition employed their authority to control the Path and exclude undesirable elements from their congregations and realms is still an open question. An answer is only partly provided in this article through a discursive analysis of manuals and narratives by contemporary Sufi authors that clearly delineate the borderlines of affiliation with the communities of the true Sufis and denounce the irreligious practices of antinomians and nonconformist wrongly linked with Sufism. ${ }^{5}$ The role played by the political rulers of the time in marginalizing pseudo-Sufis and suppressing antinomians is

${ }^{3}$ For key studies that discern the beginning of the consolidation of mainstream Sufism in late fourth/tenth-century Khurasan, see Chabbi, "Remarques sur le développement historique des mouvements ascétiques et mystiques au Khurasan;" Meier, $A b \bar{u} S a$ ' $\bar{l} d-i A b \bar{u}$ al-Hayr (357-440/967-1049): Wirklichkeit und Legende. Their observations have been eloquently elaborated upon by Malamud, "Sufi Organizations and Structures of Authority in Medieval Nishapur." A considerable number of studies have focused on pivotal figures in the development of the Sufi tradition. For recent contributions, see Thibon, L'oeuvre d'Abu 'Abd al-Rahmân al-Sulamî (325/937-412/1021); Nguyen and Ingalls (eds.), Al-Qushayrì and His Legacy.

${ }^{4}$ On which see especially Karamustafa, God's Unruly Friends: Dervish Groups in the Islamic Later Middle Period, 1200-1500.

${ }_{5}$ On the severe and unprecedented denunciation of pseudo-Sufis by later Sufi masters, see Geoffroy, Le Soufisme en Égypte et en Syrie sous les Derniers Mamelouks et les Premiers Ottomans: Orientations Spirituelles et Enjeux Culturels, pp. 176-182. 
another important issue considered in the final part of the article, which focuses attention on the Syrian urban scene during the seventh/thirteenth century under the reign of the Ayyubids and early Mamluks.

\section{Setting the Boundaries}

Clearly, as an inner-worldly tradition, Sufism contained an intensely self-critical strain from its very beginnings. Deprecation of extreme forms of mysticism and asceticism and, in particular, opposition to abstaining from seeking a livelihood as countering the norm of living within society, may be traced back to the pre-classical Sufism of Abu 1Qāsim al-Junayd (d. 298/940). The examples of al-Hārith al-Muhāsibì (d. 243/857) of the early Baghdad school and the circle associated with moderate Sunnism that congregated in Basra around Abu Hātim al'Atțār (d. 260's/874-84) come to mind. ${ }^{6}$ However, it was only with the articulation of what came to be termed "the science of Sufism" ( 'ilm altasawwuf), beginning in the late fourth/tenth century, that more systematized efforts were made to delineate the boundaries of the Sufi tariqa as both a path to God and a community of disciples and followers.

The need to set up a rigid and precisely defined boundary between Sufism and its margins is lucidly expressed in Kitäb al-luma' fi l-tasawwuf (The Book of Light Flashes) by Abū Nașr al-Sarrāj al-Ṭūsī (d. 378/988). Supporting his discussion with authoritative statements attributed to the founding fathers of the tradition, this is how the renowned author of one of the earliest classical Sufi textbooks opens his chapter on the erroneous Sufis:

[In all that concerns Sufism,] we have reached a clear-cut borderline (ilā makānin mithla haddi l-sayfi): anyone who errs is doomed to fall into the flames of fire. ... Verily, there is no graver error than erring in [the science of] Sufism (tașawwuf). For Sufism is composed of mystical states and stations, degrees, quests, and allusions (ahwāl wa-maqāmāt wa-marāti, wa-irādāt wa-ishārāt). Anyone who dares to cross the line in these matters arouses the fury of God. ${ }^{7}$

It would be difficult to trace the various groups linked to Sufism and yet rejected by shar ${ }^{i} \bar{l}$-minded Sufi shaykhs and outside critics

${ }^{6}$ See Melchert, "Basran Origins of Classical Sufism."

${ }^{7}$ Abū Naṣr al-Sarrāj al-Ṭūsī , The Kitāb al-luma 'fì 'l-tașawwuf, ed. Nicholson, p. 409. 
alike. Yet al-Sarrāj devoted a considerable portion of his work to listing and classifying them and to displaying in detail the source and nature of their errors. ${ }^{8}$ Significantly, in their attempt to define the various essentials of the Sufi path and categorize the suspect and rejected groups, the authors of the classical Sufi manuals applied the terminology and legal rhetoric used in judicial works. ${ }^{9}$

The first broad category al-Sarrāj singled out is that of those who err in the fundamental principles $(u s \underline{u} l)$ of the mystical path. Among the various groups circumscribed under this category is a group in Baghdad who thought that in renouncing their own qualities they have entered God's qualities; a group in Iraq who claimed to lose all their senses in ecstasy and thus to transcend sensory phenomena; and a group in Syria and in Basra who claimed to have spiritual vision of God in this world. ${ }^{10}$ These erring libertines lost all restraint in their claim to have attained proximity to God and annihilation in Him.

But there is another category of erroneous, false Sufis. These are those who err in the derivatives ( fur $\left.^{\top}\right)$-that is, in the manners, ethics and spiritual feelings that must be manifested in the doings and sayings. Indeed, al-Sarrāj, and later authors of Sufi manuals, placed no less emphasis on Sufism as a code of behavior than as a mystical path. For them, Sufi modes of knowing were closely related to specifics of behavior, dress, ritual and communal life. They thus determined to set forth the fundamental norms and praxis to be associated with the true Sufis. Al-Sarrāj, who dedicated over a fourth of his work to Sufi practice, put it this way:

Whoever considers himself as belonging to this group ( $t \bar{a}$ 'ifa) but does not adhere to three fundamental principles $(u s \bar{u} l)$ that are the basis of all true Sufism, is wrong. These are: avoidance of the forbidden, performance of all obligatory dictates of divine law ( $f a r \bar{a}$ ' $i d$ ), and renunciation of the world and its denizens, let alone what the Prophet considered necessary for the believer: '[Prophet] there are four things that are in this world but not of it: a scrap of bread to satisfy your hunger, a piece

${ }^{8}$ For an attempt to match several of the groups listed by al-Sarrāj with those discussed by his contemporary al-Muțahhar b. Țāhir al-Maqdisī in Kitāb al-bad'wa-l-ta 'rìkh, see Karamustafa, Sufism: The Formative Period, pp. 161-162. But as he himself admits, it would be hazardous to attempt a one-to-one correspondence on the basis of the meager evidence provided by the latter about such Sufi groups as the Malāmatiyya, the Shawqiyya and the Husniyya.

${ }^{9}$ Ohlander makes this important point in Sufism in an Age of Transition, pp. 244-245.

10 Al-Sarrāj, Kitāb al-luma', pp. 117-120. 
of cloth (khirqa) to cover your nakedness, a tent (bayt) to shelter you, and a virtuous wife you can trust.' Worldliness in other respects is an absolute barrier between God and his servant. ${ }^{11}$

The identification of true Sufis as those who model their values and behavior after the simple ascetic and community-oriented piety of the Prophet was, of course, not new with the appearance of the classical Sufi textbooks that gave Sufism its final shape and normative tone. Replication of such fundamental behaviors as renunciation of worldliness in favor of recollection and acts of worship, self-sufficiency and contentment with a modicum of food, drink and clothing is ascribed both in Sufi and non-Sufi sources to the earliest pious and asceticstruthful followers of the Prophet and models of virtues to be followed, later to be known as Sufis. But al-Sarrāj, followed by 'Alī Hujwirī (d. 456/1063 or 464/1071-72) and Abū 'Abd al-Raḥmān al-Sulamī (d. 412/1021), did more than define a code of ethical behavior with which anyone seeking to belong to the community of the true Sufis should comply. They also took pains to distance themselves from imitators of the Sufis (al-mutashabbihün bihim), who wrongly associate themselves with true Sufism, and they endeavored to examine the sincerity, purity of heart and inner intent of others. ${ }^{12}$

Al-Sarrāj uses the term al-tahallì (literarily "beautifying oneself") to denote the imitation (tashabbuh) of pious men in words and deeds. Some imitators vainly suppose that they can become Sufis by wearing garments of wool and eschewing worldly goods, by learning mystical allegories and technical expressions, or by fasting, praying and weeping. Others participate in assemblies of music, dancing and ecstasy in order to resemble the Sufis. For al-Sarrāj, semblance of the ecstasy of Sufi devotions and manners without inner intention and perfect inner sincerity (ikhlâss) is not only to no avail, but should be regarded as blemished and impure. ${ }^{13} \mathrm{He}$ who mechanically and deliberately simulates the words and deeds of the Sufis is "like a man who cannot distinguish a precious jewel from a bead made of glass." ${ }^{14}$ For al-Sulamī,

11 Al-Sarrāj, Kitāb al-luma', pp. 409-410.

${ }^{12}$ On the opposition to "imitation" (tashabbuh) in the Sufi classical literature by al-Sarrāj and his like-minded contemporaries, see Salamah-Kudsi. "The Idea of Tashabbuh," p. 177.

13 Al-Sarrāj, Kitāb al-luma', p. 419.

14 Al-Sarrāj, Kitāb al-luma', p. 422. 
every intelligent man should "know something of the fundamentals of Sufism and the path of the Folk of Sincerity among them so that he may disassociate himself from those imitators (mutashabbihün), those who don their dress, and those who wrongly take their name (al-mutarassimün bihim), and thus not become one of them." ${ }^{15}$ Hujwirī, using a harsher rhetoric, addresses an implicit warning to imitators or false Sufis: "Those who seem to be what they are not will be soon put to shame, and their secret character revealed." 16

In brief, true Sufism cannot be simply emulated. Nor can spiritual experience be attained through ecstasy and extreme ascetic practices such as self-mortification, retirement from the world or solitude. Rather, the blessings of Sufi knowledge and affiliation with the true Sufis are conditioned inwardly on perfect sincerity and purification of the heart, and outwardly on compliance with the disciplines of their tradition and the norms and ordinances of Islam. In this respect, al-Sarrāj cites an earlier authority as reporting having seen a number of persons who, on account of their ill-regulated abstinence from food, were unable to perform their religious duties. ${ }^{17}$ The God servant's quest for inner sincerity when involving absence of regard for everything but God should be strongly rejected, since it produces recklessness and a

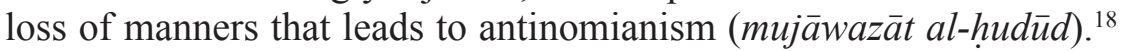
Al-Sulami, following this line, identifies the most sublime spiritual state as that in which the inner-mystical (bätin) dimension of Sufism is not given precedence over its outer (zähir) dimension, ${ }^{19}$ and places unparalleled emphasis on correct behavior. In Jawāmi' $\bar{a} d \bar{a} b$ al-șufiyya (A Collection of Sufi Rules of Conduct), apparently the first single work devoted to describing many disparate rules of conduct, the acquisition of proper manners $(a d a b / \bar{a} d \bar{a} b)$ is described as more important and praiseworthy than the accumulation of religious knowledge ( ${ }^{\prime} \mathrm{lm}$ ) or prolonged engagement in ascetic practices; any disrespect for

15 Abū 'Abd al-Rahmān al-Sulamī, al-Muqaddima fì l-tașawwuf wa-haqīqatihi, p. 84. See the English translation of the whole paragraph in Ohlander, Sufism in an Age of Transition, p. 192.

16 'Alī Hujwirī, Kashf al-mahjūb of al-Hujwirī, trans. Nicholson, p. 389. See also Salamah-Qudsi, "The Idea of Tashabbuh," p. 177.

${ }^{17}$ Al-Sarrāj, Kitāb al-luma', p. 417.

18 Al-Sarrāj, Kitāb al-luma', p. 421.

19 Al-Sulamī, Risālat al-malāmatiyya, ed. Abū 'Alā' 'Afífī, pp. 86-87. 
$a d a b$ might lead to the loss of faith in God. ${ }^{20}$ The mystical and ethical dimensions of Sufism, the bātin and the zāhir, are thus bound up together, because mystical ascent is conditioned on sincerity of the heart and inner purification that must be outwardly manifested in manners and ethics.

Moreover, anyone aspiring to belong to the community of true Sufis must attach himself to a spiritual guide (murshid) who will monitor his behavior and examine his inner world. According to al-Sarrāj, error is caused by want of a director: "He who has no guide to set him on the right path is equal to someone who enters a dark home without a lantern." ${ }^{21}$ Likewise, Hujwiri claimed that the ignorant pretenders to Sufism are those who have never associated themselves with a spiritual guide and learned spiritual discipline from a master (shaykh). ${ }^{22}$

\section{Disentangling the Solid Core}

By the fifth/eleventh century, individual effort in pursuit of the Path was no longer acceptable. Whatever the steps of spiritual progress that might lead to vision of God, "Tașawwuf has always a beginning, a culmination and intermediary stages," states al-Sulamī. ${ }^{23}$ The first station ( $m a q \bar{a} m$ ) at the very beginning of the Path is always tawba (repentance or conversion). Beginning with the classical Sufi manuals, there is evidence that the dramatic experience of conversion and spiritual renewal crystallized into a ritual practice which was administered by a shaykh, thereby marking a decisive and crucial moment of training under his instruction and guidance. ${ }^{24}$ Sufi authors living in the late fourth/tenth and early fifth/eleventh centuries, repeatedly insisted on the need for an accomplished master who would initiate the aspirant (murid) into the Path, instill in him its essential concepts and practices and guide him along its stations and states. Al-Sulamī, followed by others, urged the aspirant to seek a guide and mentor possessing wide knowledge

20 Al-Sulamī, Jawāmi' ādāb al-șūfiyya, ed. Kohlberg, p. 11 (summary of paragraph 7).

${ }^{21}$ Al-Sarrāj, Kitāb al-luma', p. 410.

22 'Alī Hujwirī, Kashf al-mahjūb, pp. 19-20.

23 Al-Sulamī, Manāhij al- 'ārifin, ed. Kohlberg, p. 25.

${ }^{24}$ For the development of the perception and practice of tawba in the formative period, see Böwering, "Early Sufism between Persecution and Heresy," pp. 52-53. 
and experience to lead him on the right course, warn him of the pitfalls along the Path and teach him to distinguish his sinful from his virtuous deeds. ${ }^{25}$ This perception was elaborated on by later authors of adab literature. For al-Qushayrī it was impossible to tread the Path without total subordination to an authoritative master. ${ }^{26} \mathrm{Al}-\mathrm{Ghaza} l \overline{1}$ presented the authoritative guide as the healer of souls. In his words addressed to the seeker of the Path: "Know that whoever treads this path (tariq) should attach himself to a shaykh, a guide and educator, through whose guidance his bad qualities will be rooted out." 27

The insistence on calling upon a master for traversing the Path, which runs like a thread through the ādāb al-muridin literature, was closely linked with the institutionalization of Sufism as a path to God. It set limits to mystical experience that leads to proximity to the divine and established ways of defining and controlling spiritual ascent. Whatever the veils separating the wayfarer from the beloved creator, every seeker of the Path must attach himself to an authoritative guide who will guard his steps and protect him from straying. To acquire the authority necessary to transmit sacred knowledge and a particular spiritual way (taríqa), this guide must have been a part of a chain of spiritual authority (silsila) transmitted from master to disciple all the way back to the Prophet. The silsila took some time to crystallize, but, as Ahmet Karamustafa observes, it is likely that the growing significance of the concept of the spiritual chain during the fifth/eleventh and sixth/twelfth centuries was bound up with an increasing emphasis on the role of the shaykh as "master of training" (shaykh al-tarbiya), as opposed to his role as "master of instruction" (shaykh al-ta 'lim). ${ }^{28}$ In his position as "master of training," the guide would supervise his disciple's conduct and consolidate his control over him to the point of being involved in his private, inner life. ${ }^{29}$

25 Al-Sulamī, Jawāmī’, pp. 66-68.

${ }^{26}$ Abū l-Qāsim al-Qushayrī, al-Risāla al-qushayriyya fì l-tașawwuf, ed. Zuriq and alBaltajī, p. 735.

${ }_{27}$ Abū Ḥāmid al-Ghazālī, Ayyuhā al-walad, p. 37.

${ }^{28}$ Karamustafa, Sufism, p. 116.

29 The designations shaykh al-tarbiya and shaykh al-ta 'ìm were coined by Ibn 'Abbād al-Rundī (d. 1390). They were first borrowed by Fritz Meier in "Hurasan und das Ende der klassischen Sufik;" Meier, "Khurāsān and the End of Classical Sufism," pp. 190-192; Meier, "The Mystic Path," pp. 117-128. 
Accounts of the lives and teachings of the Sufi shaykhs cast light on the ways their position as masters of training was understood and practiced. An early testimony concerns Abū 'Abd Allāh al-Rūdhbārī, the great mystic of Tyre (d. 369/980). Al-Qushayrī depicted him as shaykh al-tarbiya, closely monitoring the behavior of his disciples and deeply concerned with safeguarding the reputation of members of his group as righteous people among the community of their fellow believers:

\begin{abstract}
It is related that one day Abū 'Abd Allāh al-Rūdhbārī was following the fuqarā' . It was his habit to follow them. They directed their steps to a private house for the performance of the supplication prayer $\left(d a a^{\prime} w a\right)$. Someone was heard to remark: "These people take things unlawfully," and added, "One of them did not pay me back one hundred silver coins (dirham) he borrowed from me, and I know not where I should find him." The house where they gathered belonged to a "lover" (muhibb) of this group ( $t \bar{a}$ ' $i f a)$, and when they entered it, Abu 'Abd Allāh al-Rūdhbārī said to the house owner, "If you care about my peace of mind, give me one hundred dirhams." The request was immediately granted. He then ordered one of his close companions (ash $\bar{a} \bar{b})$ ): "Take the money to the greengrocer with the following explanation: Here is the money that one from among our group borrowed from you. He now returns the loan in the hope of your forgiveness for the belated repayment." And the disciple did so. On their way back from the $d a^{6} w a$, they all stopped at the shop of the greengrocer, who, upon seeing them, started to praise them, exclaiming: "These are righteous and trustworthy worshipers, may God bless them."
\end{abstract}

Al-Rūdhbārī concludes the episode with the words: "The most repulsive [man] is the stingy Sufi." ${ }^{30}$ This last statement is also attributed to him in Bāb al-tasawwuf (the chapter on the Sufi doctrines) of alQushayrī's Risāla. ${ }^{31}$

Biographical accounts composed in later periods provide ample indications of the total dependence of the disciple on his master for mystical experience and ascent. A most telling testimony is contained in the biographical entry of Shaykh Abū Bakr b. Qawām al-Bālisī, the revered Sufi and Shāfi'i scholar of the village of Bālis in the Jazira region (d. 658/1259). ${ }^{32}$ In it Ibn Qawām describes the mystical expe-

30 Al-Qushayrī, al-Risāla, pp. 415-416.

31 Al-Qushayrī, al-Risāla, p. 281.

${ }^{32}$ In his biographical collection of the celebrated legal scholars of his Shäfi'í rite Țabaqāt al-shāfi 'iyya al-kubrāa, Tāj al-Dīn al-Subkī devoted an extensive biography to Ibn Qawām. His biography is also to be found in Ibn al-Mulaqqin, Tabaqāt al-awliya ', and in several comprehensive dictionaries about a great number of 'ulam $\bar{a}$ '. These include Shams 
rience connecting him to the Prophet and bringing him close to sacred reality:

I have suffered many hardships while traversing the initial mystical stations of the Path, and shared my experience with the shaykh. The shaykh said: "If you dare to tell to anyone else, I shall whip you." He ordered me to absorb myself in the worship of God and pay no attention to my mystical experience.

I clung to the shaykh's company and obeyed his orders, until that night when I asked his permission to visit my blind mother.... The shaykh allowed me to go and said, "A wondrous event will occur to you tonight. Endure it, do not shy away." While on my way, I heard a voice from heaven. I raised my head, and there was light in the shape of a silsila, blended one into the other. The chain wound around my back until I could feel its chilliness.

I returned to the shaykh and told him about the extraordinary experience. The shaykh extolled God and kissed me between the eyes. He said: 'O' my son, from now on, the grace of God will wind around you. Would you know what this chain is? ... This is the sunna of the Messenger of God," and thereupon he allowed me to tell [others] about my mystical experience. ${ }^{33}$

Only through his shaykh could Ibn Qawām attain proximity to God and his Messenger. The shaykh would lend meaning to the vision of his disciple, who could not on his own advance the claim to have attained direct connection to the Prophet. The interpretation of the dream was probably intended not only to relieve the disciple of preoccupation with his awesome experience, but also to provide the shaykh with a means of accessing the disciple's inner life and, thereby, of controlling his spiritual experience.

Elsewhere in his biography, Ibn Qawām is portrayed as supervising the mystical unveiling of his disciple while warning him against crossing the boundaries of the knowledge with which the Prophet was blessed. His disciple, Shams al-Dīn al-Khābūrī, related:

I went out to visit the shaykh, and it entered my mind to ask him about the spirit. But when I came into his presence my awe of him made me forget the question I had intended to ask. I bade him farewell and proceeded on my way. The shaykh sent one of the Sufis after me, who said to me: "Speak to the Shaykh." So I returned to him. When I entered his presence, he said to me, "O' Ahmad." I said: "At your

al-Dīn Muḥammad al-Dhahabī, al- 'Ibar fì khabar man ghabar, 5, pp. 250-251; Ibn Shākir al-Kutubī, Fawāt al-wafayāt, 1, pp. 148-150; and Ibn al-'Imād al-Hanbalī, Shadharāt aldhahab fi akhbār man dhahab, 5, pp. 295-296.

33 Tāj al-Dīn al-Subkī, Tabaqāt al-shāfi 'iyya al-kubrāa, 8, pp. 401-402. 
service, my master." He said: "Do you not read the sacred Qur'an?" and ordered me to read [the verse]: '[Prophet], they ask you about the Spirit. Say, The Spirit is part of my Lord's domain. You have only been given a little knowledge.' (Qur'an: 17:85). Then the shaykh turned to me saying: "My son, how can we ask about a matter which the Messenger of God, may God pray for him and give him peace, does not speak of?"34

Gradually, new, more institutional forms emerged that embodied the unquestionable submission to the master's authority, which carried with it also the adoption of vigils, litanies, devotions and other forms of worship that together constituted his spiritual path or tariqa. Most common in the early phase of the crystallization of the spiritual paths were the taking of the oath of fidelity (the 'ahd) and the investiture with the patched cloak or shawl (the khirqa). When Abu l-Najīb alSuhrawardi (d. 1097/1168), author of one of the most widely read Sufi manuals, tells of a lay believer who refused to wear the khirqa after having been told by him about the strict duties and regulations imposed on those wearing it, we may assume that in the world he inhabited the practice already carried enough weight to ensure the surrender of the disciple to his master and a binding relationship with him. ${ }^{35}$ Having heard about Abū 1-Najīb's response, his master, Shaykh Aḥmad alGhazālì, scolded him, saying:

If we impose all the duties and strict regulations of the Path on our new disciple he will turn away from us. But if we invest him with the patched cloak and let him imitate the Sufis and participate in their gatherings, one expects he will obtain some of their blessings, and by imitating their behavior and customs he most probably can also attain to some of their inner states. ${ }^{36}$

This last account provides us also with a clear indication of a profound change in the concept of imitating the Sufis (tashabbuh bi-lsúfiyya). The early negative inference of the word mutashabbih was no longer used in the writings of such influential Sufi masters as Abu 1-Najīb and his famous nephew 'Umar al-Suhrawardī (d. 632/1234). Those who had true intentions to imitate the Sufis in their morals and patterns of behavior were warmly welcomed to join their company

${ }^{34}$ Tāj al-Dīn al-Subkī, Ṭabaqāt al-shāfi 'iyya al-kubrā, 8, pp. 407-408.

35 Abū Hafș 'Umar al-Suhrawardī, 'Awārif al-ma 'ārif, p. 96.

${ }^{36}$ Abū Ḥafṣ 'Umar al-Suhrawardī, 'Awārif al-ma 'ārif, p. 97. 
even though they were unable (or did not intend) to perform Sufi ascetic practices and spiritual duties. ${ }^{37}$ Many dispensations (rukhas ) were granted by Abū 1-Najīb to the "truthful imitators" (al-mutashabbihūn al-șadiqūn), allowing them to partake of the spiritual life of the Sufi community without forsaking their material possessions and social connections..$^{38}$ But while developing the conceptual and legal apparatus that opened the door to this category of lay affiliates, 'Umar alSuhrawardi considered the mutashabbih as the lowest in the Sufi community and carefully delineated the contours of its solid core. Typology and gradation served as a prime literary tool for internal differentiation and thus also as a mechanism for control of the Path. The highest degree in the pyramid of companions in 'Umar al-Suhrawardi's classification is that of aspirant (murid): a seeker of the Path undertaking the rigors of self-imposed deprivation implicit in the rule of conduct of the tariqa and actively engaged in a comprehensive program of spiritual progress under the direction of an accomplished shaykh. ${ }^{39}$

\section{In the Face of New Challenges}

By the end of the earlier middle period, mainstream Sufis had to face new challenges. Some lay affiliates partaking in Sufi gatherings practiced a mode of behavior and rituals that contradicted the customary ways of normative Sufi tradition. 'Umar al-Suhrawardī's writings well illustrate the need to cleanse the Sufi community of improper praxis. His condemnations of what he described as the spread of fas $\bar{a} d$ (literally, "corruption") during the Sufi "concert," the sama', were repeated from then on by legal scholars and mainstream Sufis living in the Mamluk period. ${ }^{40}$

${ }^{37}$ For an in-depth discussion of this change, see Salamah-Qudsi, "The Idea of Tashabbuh," pp. 179-197.

${ }_{38}$ Abū 1-Najīb al-Suhrawardī, Kitāb àdāb al-murìdīn, pp. 80-99; Abū 1-Najīb alSuhrawardī, A Sufi Rule for Novices; Kitāb Àdāb al-Murìdīn of Abū al-Najīb alSuhrawardī, pp. 72-83. For a detailed discussion of this section, see Netton, "The breath of felicity: adab, ahwāl, maqūmāt and Abū Najīb al-Suhrawardī."

${ }^{39}$ For a detailed exposition of the Sufi hierarchy as formulated by 'Umar alSuhrawardī, see Ohlander, Sufism in an Age of Transition, pp. 226ff.

${ }^{40}$ For examples, see Frenkel, “Mutasawwifa versus Fuqara'," pp. 301-305. 
According to "Umar al-Suhrawardi, the semblance of ecstasy (takalluf) in the rituals of $\operatorname{sam} \bar{a}$ ', induced by music, dancing and casting one's patched cloak to the singer, is not rejected in itself; it should be considered impure only if it is motivated by love of the world and human instincts. This type of takalluf must be sharply differentiated from the sincere type and harshly rebuffed. ${ }^{41}$ In his words:

We have already mentioned the sound and proper intent of the sam $\bar{a}$ ' among the righteous ( $a$ hl al-sidq), and the intensification of dissent (fitna) concerning sama $\bar{a}^{\text {: }}$ Infallibility in $s a m \bar{a}^{\prime}$ has come to an end...

The performers of $\operatorname{sam} \bar{a}^{\prime}$ [in our age] disregard the rules of proper worship and conduct. Sometimes they even bring foodstuff to the assembly... Indeed, the sam $\bar{a}$. has become an object of the soul in its quest for lusts, delight of heedlessness, and ecstasy. Clearly, men of faith denounce this type of assembly. ${ }^{42}$

Muḥammad 'Imād al-Dīn (d. 655/1257), 'Umar al-Suhrawardī's own son and successor to the directorship of his endowed Baghdad cloister (ribāt), warns of frivolous imitators, undesirable "newcomers" who violate the rules and disciplines of proper conduct in the Sufi pious residence:

A group of young men (ahdāth) appeared in our generation, who know nothing about Sufism, let alone [the custom of] dying the garments ${ }^{43}$ and dressing with the undergarment (zīr-jāme). ${ }^{44}$ They quarrel [even] over a piece of bread wherever they assemble... They turn "wrong" (munkar) into "right" (ma'rüf) and "right" into "wrong."... Those who aspire to resemble the Sufis fail to comprehend the meaning of affiliation with them and their rules of conduct. ... They enter into the dwelling places of the Sufis with carelessness and disrespect with no one reproaching them and forbidding their behavior. ${ }^{45}$

By the close of the sixth/twelfth century, mainstream Sufis directed their efforts as arbiters of the central moral tenet of "commanding right

${ }^{41}$ See Salamah-Qudsi, "The Idea of Tashabbuh,” pp. 186-188. For the conditions of the approved $\operatorname{sam}_{\bar{a}}$ ' stipulated by 'Umar al-Suhrawardī, see Ohlander in Sufism in an Age of Transition, p. 242.

${ }^{42}$ Al-Suhrawardī, 'Awārif al-ma 'ārif, p. 187.

${ }^{43}$ Perhaps in dark blue (azraq), the preferred color for the garment since it easily hides the dirt which comes with the state of voluntary poverty (faqr); or green, being the color of the Prophet. See Ohlander, Sufism in an Age of Transition, p. 213, n. 60, for a more thorough textual interpretation of these terms.

${ }^{44}$ A part of the Sufi cloak which completes the costume (libās) of the true worshiper.

45 'Imād al-Dīn Muhammad, Zād al-musāfir wa-adab al-hạdir, Köprülü Library, Istanbul, MS 1603/2, fol. 13a-b. I would like to thank Erik Ohlander for forwarding to me a digitized version of the manuscript. 
and forbidding wrong" (al-amr bi-l-ma'rüf wa-l-nahy 'an al-munkar) to the public sphere as a whole. Sufi shaykhs joined with legalists in denouncing the irreligious practices of antinomian groups that sprang up in the Arab Near East and beyond. ${ }^{46}$ Some ascetics and Sufi groups, such as the muwallahūn (fools for God), the Haririyya, the Șaydariyya and the Qalandariyya, outwardly defied the ideals of Muslim piety by living in a state of ritual impurity, wearing filthy clothes, and not praying or fasting. Improper or provocative attire, characteristic of some antinomians generally known as dervishes, was understood as an expression of revolt against established norms and authorities, and was perceived as threatening to social identities and boundaries. ${ }^{47}$

Contemporary and later Sufi authors repeatedly called for strict adherence to the Holy Law and censured deviant behavior. Consistently featured in their writings is the clear distinction drawn between mainstream Sufism and its margins. In a very short untitled testament that opens with the sentence: "These are the instructions to the Sufi aspirants (wașiyyat al-murìdin)," 'Umar al-Suhrawardī, without referring to any specific group, strongly advises his audience:

\begin{abstract}
Be not accounted amongst the ignorant and mindless Sufis (min juhhāl al-süfiyya wa-ghirratihim). Those people who sit in the markets and recite [in the hope of collecting donations]. You should know that these [reciters] are robbers and brigands who block the roads on which Muslims travel and prevent them from carrying out the duties of the religion of Islam. Oh my son, adhere to the norms of Islam (sunna) and stay close to the believers in true faith. Avoid new doctrines and customs. Every religious innovation (muhdatha) is a severe error. Oh my son, avoid the company of beardless youth, women, innovators of new religious traditions, wealthy persons and the rabble. If you do not fulfill these guiding instructions you will lose your religion. ${ }^{48}$
\end{abstract}

The muwallahūn seem to be a distinctly Damascene phenomenon and far from being a marginal element in society. They were influenced by mysticism and driven to individuality, which chose degradation and life on the margins of society as a personal spiritual path. While for some of the people of Damascus they were recognized as friends of God (awliy $\left.\bar{a}^{\prime}\right)$ possessing wondrous powers, for others-in particular

${ }^{46}$ See the examples in Karamustafa, God's Unruly Friends, especially, pp. 5-6.

47 Karamustafa, God's Unruly Friends, pp. 18-19.

48 Jerusalem, JNUL, Yahuda Collection of Arab manuscripts \#\# 179 (3), f 4b (II.912); cited by Frenkel, "Mutasawwifa versus Fuqara"” p. 302. 
theologians and learned people-they were mindless wretches or insane $(\operatorname{majn} \bar{u} n){ }^{49}$

The veneration of the muwallah, either in his lifetime or at his tomb, must have been a source of concern for mainstream Sufis and legalists. Descriptions of their improper apparel and impiety could be employed as a tool for provoking sentiments of disrespect and rejection. Consider, for example, Shaykh Yūsuf al-Qamīnī (d. 657/1259), one of the bestknown muwallahūn in Damascus, whom the people regarded as a "friend of God" (walī). Homeless, bare-headed and filthy, his overlong robe sweeping the streets, he appears in the biographical dictionaries of scholars as a madman who was constantly in a state of ritual impurity (najāsa).$^{50}$ The Egyptian Sufi, Safî l-Dīn b. Abī l-Manșūr (d. 682/1283), who met 1-Qaminin in the Umayyad Mosque of Damascus, noted in his Risāla that he neither prayed nor fasted..$^{51}$ As Denis Gril points out in his introduction to the Risāla, Șafi l-Dīn was particularly interested in narrating the exploits of the muwallahūn, namely their inclination to defy established social custom. ${ }^{52}$

The disciples of 'Alī al-Harīin (d. 645/1248), the foremost representative of antinomian Sufism in Syria in Ayyubid times, were known in Damascus as "așhāb al-ziyy al-munāfi li-l-sharì 'a," meaning those whose dress runs counter to the regulations of the shari ' $a .^{53}$ The historian and religious scholar Abū Shāma complains that they were even worse on the inside than on the outside (bätinuhum sharrun min zăhirihim) ${ }^{54}$ Ibn Kathìr, who devoted a biographical entry to al-Harìrī in his famous chronicle al-Bidāya wa-l-nihāya, describes the spread of corruption caused by his presence and activity: many sons of distinguished

${ }^{49}$ On the muwallahūn in the Syrian urban scene of the sixth/twelfth and seventh/thirteenth century, see Pouzet, Damas au vii ${ }^{e} / x_{i i}{ }^{e}$ siècle: Vie et structures religieuses d'une métropole islamique, pp. 222-226; Meri, The Cult of Saints among Muslims and Jews in Medieval Syria, pp. 91-100; Talmon-Heller, Islamic Piety in Medieval Syria: Mosques, Cemeteries and Sermons under the Zangids and Ayyūbids (1146-1260), pp. 241-242. See also Dols, Majnūn: The Madman in Medieval Islamic Society, pp. 378-410.

${ }^{50}$ For accounts about al-Qamīnī in standard biographical dictionaries, see Pouzet, Damas au viie/xiii siècle, p. 224; Talmon-Heller, Islamic Piety, p. 240.

${ }^{51}$ Gril, La Risāla de Safì al-Dīn ibn Abì l-Manșūr ibn Zāfir: Biographies de maîtres spirituels connus par un cheikh égyptien du VII $/$ XIII e siècle, p. 190 (French, p. 88 Arabic).

${ }_{52}$ Gril, La Risāla de Safì al-Dīn ibn Abī l-Manșūr ibn Zāfir, pp. 40-41.

${ }^{53}$ On al-Harīīi, see Pouzet, Damas au viie/xiii siècle, pp. 220-221.

54 'Abd al-Raḥmān Abū Shāma, Tarājim rijāl al-qarnayn al-sādis wa-l-sābi', ed. alKawtharī, p. 180. 
local families were attracted to his path and adopted his attire, and a huge crowd participated in assemblies of music and dancing and gazing at the beardless youth convened by him and over whom he presided. ${ }^{55}$

The dervish community of the Qalandars, who emerged as a distinct group in Damascus and Damietta during the early decades of the seventh/thirteenth century, represented a new form of religious renunciation manifested in total poverty (faqr), begging or alms taking, homeless wandering and celibacy. ${ }^{56}$ Jamāl al-Dīn al-Sāwujī, leader of Qalandariyya in Damascus (d. 630/1232), dwelt in a lodge (zāwiya) in Bāb al-Saghīr cemetery. He "turned away from the world" and shaved his head, face and eyebrows. Ibn Kathir relates that after his death, the evil practices of the Qalandars intensified, and demanded that they be punished, as some of the fuqahä ordered in their legal decree. ${ }^{57}$

Occasionally, the political authorities supported members of the mainstream Sunni camp against their rivals. They stepped in in order to restore peace and order. Two of the best-known examples concern the Qalandars and the Hariiriyya, who established roots and gained popularity in the urban Syrian scene. Ibn Kathir relates that the Qalandars of Damascus were "suppressed" by the Ayyubid prince al-Malik al-Ashraf since they disregarded the principles of the shari ${ }^{\circ}$. Later on, the Mamluk sultan, Hasan, issued a decree forcing them to wear "Islamic dress" and ordered that the disobedient be punished. ${ }^{58}$ Al-Harìì, who was harshly condemned and even found deserving of death by several of the leading Damascene fuqahä, was arrested by al-Malik al-Ashraf in 628/1231. By the end of the decade, he and his disciples had been banished from Damascus, as had the dervishes of the Qalandariyya. ${ }^{59}$

\section{Conclusion}

During the earlier middle period, mainstream Sufis took pains to delineate the boundaries of affiliation with their congregations and

${ }^{55}$ Ibn Kathīr, al-Bidāya wa-l-nihāya fì l-ta'rīkh, 13 p. 173.

${ }^{56}$ On the formation of the Qalandari path around the activity of its master, Jamāl alDīn al-Sāwujī, see Karamustafa, God's Unruly Friends, pp. 39-52.

${ }^{57}$ Ibn Kathīr, al-Bidāya, 13, p. 196; 14, p. 274.

${ }^{58}$ Ibn Kathīr, al-Bidāya, 14, p. 274.

59 Ibn Kathìr, al-Bidāya, 13, p 173. 
realms, and exclude undesirable elements. Earlier formulators and prominent representatives of mainstream Sufism, discussed at the beginning of this article, defined the fundamental beliefs and practices of the spiritual tradition of Islam and set up the boundaries between true Sufism and its margins. They divided the erroneous, "false" Sufis into categories, recorded unacceptable practices, and warned rejected or suspect individuals and groups not to associate themselves with genuine Sufis. They were followed by a generation of Sufi masters who, while opening the door to lay affiliates, differentiated between frivolous and sincere imitators, and delineated the various ranks in the Sufi congregation, thereby responding to the expansion of their realm beyond the small core of masters and disciples. By the end of the earlier middle period, mainstream Sufis were acting as guardians of normative Islam against the irreligious practices of new antinomian groups associated with Sufism that had gained influence in the Syrian milieu. Together with scholars of the established madhhabs, they directed their efforts to the public sphere as a whole.

The involvement of the ruling authorities of the time in the inner dynamics of medieval Sufism merits a comprehensive inquiry based on Sufi and non-Sufi texts. With regard to the Eastern Arab lands, several general observations and lines for further inquiry may be suggested:

a. By founding and lavishly endowing Sufi institutions (khānqā $h \mathrm{~s}$, ribāts, and zāwiyas), the ruling elite of military lords-the Seljuks, Zangids, Ayyubids, and later on the Mamluks-helped structure the Sufi experience and establish the boundaries of mainstream Sufism. ${ }^{60}$ It stands to reason that the proliferation of state-supported institutions furthered the concentration of authority in the hands of the masters who presided over them, and who manipulated their exclusive authority over their disciples and followers to establish hierarchies and bar the affiliation of undesirable elements with their communities and realms. ${ }^{61}$

${ }^{60}$ The piety and generosity shown by the Seljuks and their successors toward Sufi institutions have received considerable attention. For a recent contribution see Ephrat, Spiritual Wayfarers, Leaders in Piety: Sufis in Medieval Palestine, pp. 76-78, 109-117, 135-139.

${ }^{61}$ Compare Ovamir Anjum's argument that the spread and development of Sufi institutions that enjoyed lavish donations from Mamluk patrons served to accelerate the change from the fluidity of the early mystical wayfarer's environment to the structured, authoritarian, master-disciple relationship as a model of social belonging to the emerging Sufi orders (tarīqas): Anjum, "Medieval Authority and Governmentality," pp. 80-81. 
b. The role played by the rulers of the time in supporting mainstream Sufism and in marginalizing the undesirable and rejected elements was an integral part of their general policy of strengthening what may be labeled the mainstream Sunni camp (referred to as ihy $\bar{a}$ ' alsunna and imattat al-bid' $a$ by contemporaries) against its rivals. Ecstatic and antinomian Sufis - such as radical Hanbalī theologians, philosophers or claimants to prophecy - were regarded as a threat to established norms and authorities, and were thus a concern of the political establishment as well. ${ }^{62}$

c. The suppression of deviants by Muslim rulers was rare and never matched the harsh steps taken against heretics by rulers in the medieval Christian world. Nor did there exist institutionalized, legally constituted procedures of punishment in the medieval Muslim world. Still, once in a while rulers would join hands with arbiters of true religion in the public sphere; they would step in to secure public order and severely punish threatening elements, among them antinomian Sufis.

\section{Sources and bibliography}

\section{Sources}

Abū Shāma, 'Abd al-Raḥmān, Tarājim rijāl al-qarnayn al-sādis wa-l-sābi', M.Z. al-Kawtharī (ed.), Cairo, 1947.

Al-Dhahabī, Shams al-Dīn Muhammad al- Ibār fì khabar man ghabar, Ṣ. al-Dīn al-Munajjid and F. Sayyid (ed.), Kuwait, Dār al-Maṭbū eât wa-l-Nasr 1961-1962.

Al-Ghazālī, Abū Ḥāmìd, Ayyuhā l-walad, Tawfìq al-Șabbāgh (ed.), Beirut, alLajna al-Duwaliyya li-Tarjamat al-Rawā'i i', 1959, 2nd edition.

Hujwīīi, 'Alī b. Uthmān al-Jullābī, Kashf al-mahjūb, Reynold A. Nicholson (trans.), London, Luzac 1976.

Ibn al-'Imād al-Hanbalī, Shadharāt al-dhahab fì akhbār man dhahab, Beirut, n.d. Ibn Kathīr, Abū l-Fidā, al-Bidāya wa-l-nihāya fì l-ta'rìkh, Cairo, Mațba'at al-Ṣalafiyya, 1932.

${ }^{62}$ See Talmon-Heller's Islamic Piety (pp. $227 \mathrm{ff}$.) on the concern of the Ayyubid political rulers with what she calls the content of struggles against impiety and religious dissent and their support for the construction of boundaries between right and wrong. For a different interpretation, see Michael Chamberlain's argument that political considerations were disguised as debates about religion in thirteenth-century Damascus: Chamberlain, Knowledge and Social practice in Medieval Damascus, 1190-1350, pp. 167-173. 
Ibn Shākir al-Kutubī, Fawāt al-wafāyāt, Muhammad Muḥyī l-Dīn 'Abd al-Ḥamīd (ed.), Cairo, Maktabat al-Nahḍa al-Mișriyya, 1951.

Al-Qushayrī, Abū l-Qāsim, al-Risāla al-qushayriyya fì 'ilm al-tașawwuf, M. Zuriq and 'A. al-Balțajī (eds.), Damascus and Beirut, Dār al-Khayr,1988.

Al-Sarrāj, Abū Nașr al-Ṭūsī, The Kitāb al-Luma 'fì'l-Taṣawwuf, Reynold A. Nicholson (ed.), London, Luzak, 1963.

Al-Subkī, Tāj al-Dīn, Țabaqāt al-shāfi 'iyya al-kubrā, 'A.F.M. al-Ḥilw and M.M. al-Tanāhī (ed.), Cairo, Maṭba'at 'Īsā al-Bābī al-Halabīi, 1964-1976.

Al-Suhrawardī, Abū Hạș 'Umar, 'Awārif al-ma 'àrif, Cairo, Dār al-Kitāb al'Arabī, 1966.

Al-Suhrawardī, Abū 1-Najīb, Kitāb ādāb al-murīdīn, Menahem Milson (ed.), Jerusalem, Jerusalem Studies in Arabic and Islam, 1978.

Al-Suhrawardī, Abū l-Najīb, A Sufi Rule for Novices. Kitāb Ādāb al-Murìdīn of Abū al-Najīb al-Suhrawardī, Cambridge, MA, Harvard University Press, 1975.

Al-Sulamī, Abū 'Abd al-Raḥmān, Jawāmi' ādāb al-șūfiya, E. Kohlberg (ed.), Jerusalem, Institute of Asian and African Studies, Hebrew University, 1976.

Al-Sulamī, Abū 'Abd al-Raḥmān, Manāhij al- 'ârifin, E. Kohlberg (ed.), Jerusalem, Jerusalem Studies in Arabic and Islam, 1979.

Al-Sulamī, Abū 'Abd al-Raḥmān, al-Muqaddima fì l-tașawwuf wa-ḥaqīqatihi, Cairo, Yūsuf Zaydān (ed.), Beirut, Dār al-Jil, 1999.

Al-Sulamī, Abū 'Abd al-Raḥmān, Risālat al-malāmatiyya wa-l-șūiıyya wa-ahl alfutuwwa, Abū 'Alā' 'Afífì (ed.), Cairo, Dār Ihyā' al-Kutub al-'Arabiyya, 1945.

\section{Bibliography}

Anjum, Ovamir, "Medieval Authority and Governmentality," in John J. Curry and Erik S. Ohlander (eds.), Sufism and Society: Arrangements of the mystical in the Muslim World 1200-1800, Abingdon, Oxon, Routledge, 2012, pp. 80-81.

Böwering, Gerhard, "Early Sufism between Persecution and Heresy," in Frederick de Jong and Bernd Radtke (eds.), Islamic Mysticism Contested, Leiden, Brill, 1999.

Chabbi, Jacqueline, "Remarques sur le développement historique des mouvements ascétiques et mystiques au Khurasan,” Studia Islamica, 46 (1977), pp. 5-72.

Chamberlain, Michael, Knowledge and social practice in medieval Damascus, 1190-1350, Cambridge UK, Cambridge University Press, 1994.

Dols, Michael W., Majnūn: The Madman in Medieval Islamic Society, Oxford, Clarendon Press, 1992.

Ephrat, Daphna, Spiritual Wayfarers, Leaders in Piety: Sufis and the Dissemination of Islam in Medieval Palestine, Cambridge, MA, Harvard University Press, 2008.

Frenkel, Yehoshua, “Mutasawwifa Versus Fuqara': Notes Concerning Sufi Dis- 
course in Mamluk Syria," in Alfonso Carmona (ed. and trans.), El Sufismo y las normas del Islam, Murcia, Editora Regional, 2006, pp. 291-307.

Geoffroy, Éric, Le Soufisme en Égypte et en Syrie sous les Derniers Mamelouks et les Premiers Ottomans: Orientations Spirituelles et Enjeux Culturels, Damascus, Institut Français, 1995.

Gril, Denis, La Risāla de Șafi al-Dīn ibn al-Manșūr ibn Zāfir: Biographies de maîtres spirituels connus par un cheikh égyptien du VII $/ X I I I^{e}$ siècle, Caire, Institut Français d'Archéologie Orientale, 1986.

Hodgson, Marshall G.S., The Venture of Islam: Conscience and History in a World Civilization. Vol. 2, The Expansion of Islam in the Middle Periods, Chicago, Chicago University Press, 1974.

Karamustafa, Ahmet T., God's Unruly Friends: Dervish Groups in the Islamic Later Middle Period, 1200-1500, Salt Lake City, University of Utah Press, 1994.

Karamustafa, Ahmet T., Sufism: the Formative Period, Edinburgh, Edinburgh University Press, 2007.

Malamud, Margaret, "Sufi Organizations and Structures of Authority in Medieval Nishapur," International Journal of Middle East Studies, 26 (1994), pp. 428442.

Meier, Fritz, Abū Sa '̀̃d-i Abū al-Hayr (357-490/967-1049): Wirklichkeit und Legende, Leiden, Brill, 1976.

Meier, Fritz, "Hurasan und das Ende der klassischen Sufik," Atti del Convengo internationale sul Tema: La Persia nel Medioevo, Rome, Accademia Nazionale dei Lincei, 1971, pp. 131-156.

Meier, Fritz, "Khurāsān and the End of Classical Sufism," in F. Meier, Essays on Islamic Piety and Mysticism, translated by John O'Kane with editorial assistance of Bernd Radtke, Leiden-Boston-Köln, Brill, 1999, pp. 189-219.

Meier, Fritz, "The Mystic Path," in Bernard Lewis (ed.), The World of Islam: Faith, People, Culture, London, Thames and Hudson, 1992, pp. 117-128.

Melchert, Christopher, "Basran Origins of Classical Sufism," Der Islam, 82 (2005), pp. 221-240.

Meri, Josef W., The Cult of Saints among Muslims and Jews in Medieval Syria, Oxford and New York, Oxford University Press, 2002.

Netton, Ian R., "The breath of felicity: adab, ahwāl, maqāmāt and Abū Najīb alSuhrawardī," in Leonard Lewisohn (ed.), Classical Persian Sufism from its Origins to Rumi, London, Khaniqahi Nimatullahi Publications, 1993, pp. 464-467.

Nguyen, Martin and Ingalls, Matthew (eds.), "Al-Qushayrī and His Legacy," Journal of Islamic Studies, $2 / 1$ (2013), Special Issue.

Ohlander, Erik S., Sufism in an Age of Transition: 'Umar al-Suhrawardì and the Rise of the Islamic Mystical Brotherhoods, Leiden-Boston, Brill, 2008.

Pouzet, Louis, Damas au viie/xiiie siècle: Vie et structures religieuses d'une métropole islamique, Beirut, Dar al-Mashreq, 1986. 
Salamah-Qudsi, Arin Shawkat, "The Idea of Tashabbuh in Sufi Communities and Literature of the Late $6^{\text {th }} / 12^{\text {th }}$ and Early $7^{\text {th }} / 13^{\text {th }}$ Century Baghdad," Al-Qantara, XXXII, 1 (2011), pp. 175-197.

Talmon-Heller, Daniella, Islamic Piety in Medieval Syria: Mosques, Cemeteries and Sermons under the Zangids and Ayyübids (1146-1260), Leiden-Boston, Brill, 2007.

Thibon, J.J., L'oeuvre d'Ab̂̂ 'Abd al-Rahmân al-Sulamî (325/937-412/1021), Damascus, IFPO, 2009.

Recibido: 01/08/2013

Aceptado: 27/02/2014 